\title{
KNOWLEDGE, ATTITUDES, RISK BEHAVIOURS AND PREVENTIVE PRACTICES ON SEXUALLY TRANSMITTED DISEASES AMONG STUDENTS IN A PUBLIC UNIVERSITY IN MALAYSIA
}

\author{
Fatimah Sham ${ }^{1,2}$, Syafiqah Yaakub ${ }^{1}$, Filzah Nur Fawati ${ }^{1}$, Siti Jazilah Fatinni ${ }^{1}$ and Ain Aqiela \\ Azamuddin $^{3}$ \\ ${ }^{1}$ Faculty of Health Science, Puncak Alam Campus, Universiti Teknologi MARA (UiTM), 42300 Malaysia \\ ${ }^{2}$ Maternofetal and Embryology Research Group, Faculty of Medicine, Sungai Buloh Campus, Universiti Teknologi MARA \\ (UiTM), 47000 Malaysia \\ ${ }^{3}$ Faculty of Computer and Mathematic, Universiti Teknologi MARA, Johor Branch, Segamat Campus, 85200 Segamat, \\ Johor, Malaysia
}

Corresponding author: Syafiqah Yaakub

Email: syafiqahyaakub97@gmail.com

\begin{abstract}
Increased rates of sexually transmitted diseases (STDs) among young adults between the ages of 15 and 24 years old had been one of the major concerns of the world. For each of the 20 million new recorded STDs cases, people within those age group were responsible for more than $50 \%$ of them. This cross-sectional study was done to determine the knowledge, attitudes, risky behaviours and preventive practices related to sexually-transmitted diseases (STDs) among undergraduate students in a public university in Malaysia. A total of 1327 university students aged between 19 and 27 years were surveyed by using a self-administered questionnaire. The majority (75.1\%) had good knowledge on STDs, and a significant number of students (53.8\%) had acceptable preventive practice. Marital status was associated not only to the students' level of knowledge but also with their preventive practices. Despite having a good knowledge of STDs, students in Science and Technology academic cluster perceived unacceptable preventive practices. This study highlighted some misconceptions about STDs, preventive practices and risky behaviours, raising concerns about a likely future rise in STD incidence. Therefore, interventions to implement strengthened health education on STD-related issues were required to bring change in practices, along with knowledge and attitudes.
\end{abstract}

Keywords: Sexually-transmitted diseases, Knowledge, University students, Prevention

\section{INTRODUCTION}

Sexually transmitted diseases (STDs) are a growing health issue among youths throughout the nation. A piece of online news published by the World Health Organization (2020) stated that nearly a billion people worldwide suffered from genital herpes and another billion from oral herpes ${ }^{1}$. It was estimated that nearly half of all new STDs cases were made up of sexually active adolescents aged $15-24^{2}$. At this age, they would experience a new phase of life and the early adulthood. The youths would undergo growth and development of physical, psychosocial, and sexual maturity, as well as the beginning of experimenting of sexual activities ${ }^{3}$. This matter becomes even more worrying when the youth would start living independently while continuing their tertiary education, or starting work in a new environment for those who do not have the opportunity to further their studies.

Recently, STDs have become the ten leading causes of uncomfortable disease in young males and the second most common cause of uncomfortable disease in the young female adults in developing countries ${ }^{4}$. In Malaysia, cases of STDs are continuously rising, and the rates of Malaysians who have been positively diagnosed with chlamydia, genital warts, and herpes were found to be increasing; including the young adults at the age of 16 to 24 as the highest contributor towards the number of STDs cases.

Another report revealed that at the end of the year 2018, an estimated 87,041 people in Malaysia were positive with HIV5.

The sensitivity of sexual related issues in Muslim countries causes formal sexual education to be only recently implemented in schools ${ }^{6}$. Sexual education in schools was quite a controversial issue that have panned to various debates on which organization; the schools or family; were responsible for educating the youngster on STDs. Some students claimed to perceive information on STDs solely from their high school, leading to a significant number of students who remained to be uneducated on STDs ${ }^{7}$. The knowledge of sexual and reproductive health among students was unsatisfactory, and some misconceptions regarding sexual problems might increase the risk of sexually transmitted infections ${ }^{8}$. Therefore, it is important to determine the awareness, perceptions, risk behaviours, and prevention practices among the university students in Malaysia on STDs in order to ensure they are conscious and aware of the dangers involved with risky sexual behaviours that may affect their health. 


\section{METHODS}

\section{Study design \& population}

This study was conducted using a descriptive cross-sectional study design. The population of this study consist of undergraduate students studied in three main campuses of public university in Selangor.

\section{Sample Size}

The study sample size was 1,327 undergraduate students from a public university. Sample was calculated using Raosoft Software with a setting of $5 \%$ margin error, $95 \%$ confidence level, with 32,294 population size and $50 \%$ of the response distribution and added with $20 \%$ of drop-out rate.

\section{Inclusion and exclusion criteria}

The inclusion criteria include all undergraduate students from three main campus under the Selangor branch which from various faculty (28 faculties) which was divided into three main academic clusters and the age range between 19-27 years old.

\section{Study survey instrument}

A self-administered questionnaire was adapted from previous studies ${ }^{9-10}$. The questionnaire collected the participants' socio-demographic and consists of four other sections; knowledge of STDs (14-items question), attitudes toward STDs (20 statements), risky behaviours (6 statements) and preventive practices on STDs (6 statements). The study instrument's content validity was accomplished through cross-checking and authentication from study field experts and the Cronbach's Alpha values was 0.88 .

\section{Data Collection}

The questionnaires were distributed and collected from students at student centres on campus. The students signed a consent form which included information on purpose, importance, and procedure of the study.

\section{Data Analysis}

The data were analyzed using Statistical Package for Social Sciences (SPSS) Version 25.0 and ChiSquare Tests were performed.

\section{Ethical consideration}

Ethical approval obtained from the Faculty of Health Science. The written consent for conducting this study was achieved from the UiTM Research Ethics Committee. A brief explanation about this study was provided at the cover page of the questionnaire. Consent must be obtained before answering the questionnaires, and the students will be briefed on the purpose of the study and the procedures for data collection. All the information kept anonymous and confidential.

\section{RESULTS}

Table 1 shows the demographic characteristic of the respondents. Most of the respondents were studying in Shah Alam campus (47.4\%), followed by Puncak Alam (41.7\%) and Puncak Perdana $(10.9 \%)$. The mean age of the respondents was $22.36(\mathrm{SD}=1.22)$. The total of female respondents $(n=898 ; 67.7 \%)$ were higher than males $(n=429$; $32.3 \%) .1295$ (97.6\%) of respondents were Malay, and the remaining $32(2.4 \%)$ respondents were from other ethnic groups from all over Malaysia. The respondents were mostly single 944 (71.1\%), and the rest were in another were in relationship $(n=366 ; 27.6 \%)$, engaged $(n=10 ; 0.8 \%)$, and married $(n=7 ; 0.5 \%)$. This study involved 1268 (95.6\%) bachelor students, and 59 (4.4\%) diploma students, among semester 1 to semester 8 , in which semester 6 contributed the highest number of participants $(24.4 \%)$, and semester 1 students were the least $(0.8 \%)$. The participation involved the non-residents' students $(54.9 \%)$ and the college dwellers (45.1\%). Students were from three academic clusters; Science and Technology (42.8\%), Social Science and Humanities (41.6\%) and Business and Management (15.6\%).

The frequency and percentage of correct and incorrect answers on knowledge of STDs among the respondents were based on Table 2 . The majority $(n=1035 ; 78 \%)$ of the respondents have heard of STDs, and 298 (22\%) of them never did or did not know about STDs. The respondents correctly identified bacteria $(72.8 \%)$, virus (69.1\%), parasites $(99.5 \%)$ and fungus $(29.5 \%)$ as the causes of STDs. HIV/AIDS (82.1\%) was the best-known STDs; however, only $7.2 \%$ of them managed to identify trichomoniasis as STDs. 1279 (96.8\%) of respondents correctly answered sexual intercourse as the modes of transmission for STDs; yet, some had misconceptions that STDs were impossible through kissing (68.9\%) and infected mother to child $(72.3 \%)$. The common signs of STDs known were ulcers in genital organ (63.3\%), discharged from the vagina $(57.8 \%)$ and penis $(55.4 \%)$, pain while urinating $(53.7 \%)$ and vaginal itching $(53.1 \%)$. Still, $94.0 \%$ failed to identify sore throat as the symptoms of STDs and incorrectly perceived contraceptive pills (33.4\%) could reduce STDs. However, the respondents knew condoms (79.5\%) and monogamy (85.5\%) can reduce STDs infection; vice versa for multiple sexual partners (94.2\%). Many were still unaware that alcohol $(60.1 \%)$ and drug intake (61.2\%) could increase one's susceptibility to STDs. Regardless, sexual abstinence $(79.5 \%)$ was believed to be the most effective way to avoid STDs. Nearly half $(47.6 \%)$ of the respondents also believed STDs could be symptom-free. Cervical cancer $(66.7 \%)$ and infertility $(50.9 \%)$ were the most known complications of STDs, but many were oblivious that stillbirth $(89.7 \%)$ and ectopic pregnancy $(73.5 \%)$ were also the complications of STDs. 
Table 1: Demographics Characteristics of the University Students $(n=1,327)$

\begin{tabular}{|c|c|c|}
\hline Variables & Frequency $(n)$ & Percentage (\%) \\
\hline \multicolumn{3}{|l|}{ Study Setting } \\
\hline UiTM Puncak Alam & 553 & 41.7 \\
\hline UiTM Shah Alam & 629 & 47.4 \\
\hline UiTM Puncak Perdana & 145 & 10.9 \\
\hline \multicolumn{3}{|l|}{ Age (Mean:22.36; SD:1.22) } \\
\hline 19-24 years old & 1291 & 97.2 \\
\hline $25-27$ years old & 36 & 2.8 \\
\hline \multicolumn{3}{|l|}{ Gender } \\
\hline Male & 429 & 32.3 \\
\hline Female & 898 & 67.7 \\
\hline \multicolumn{3}{|l|}{ Ethnic } \\
\hline Malay & 1,295 & 97.6 \\
\hline Others & 32 & 2.4 \\
\hline \multicolumn{3}{|l|}{ Marital Status } \\
\hline Single & 944 & 71.1 \\
\hline In a relationship & 366 & 27.6 \\
\hline Engaged & 10 & 0.8 \\
\hline Married & 7 & 0.5 \\
\hline \multicolumn{3}{|l|}{ Educational Level } \\
\hline Diploma & 59 & 4.4 \\
\hline Bachelor & 1,268 & 95.6 \\
\hline \multicolumn{3}{|l|}{ Current Semester } \\
\hline 1 & 11 & 0.8 \\
\hline 2 & 85 & 6.4 \\
\hline 3 & 118 & 8.9 \\
\hline 4 & 274 & 20.6 \\
\hline 5 & 195 & 14.7 \\
\hline 6 & 324 & 24.4 \\
\hline 7 & 247 & 18.6 \\
\hline 8 & 73 & 5.6 \\
\hline \multicolumn{3}{|l|}{ Residency } \\
\hline Resident & 598 & 45.1 \\
\hline Non-resident & 729 & 54.9 \\
\hline \multicolumn{3}{|l|}{ Academic Cluster } \\
\hline Science \& Technology & 568 & 42.8 \\
\hline Social Science \& Humanities & 552 & 41.6 \\
\hline Business \& Management & 207 & 15.6 \\
\hline
\end{tabular}

$S D$ denotes as standard deviation, $n$ denotes as number of participants

Regarding the respondents' attitudes towards STDs, many agreed that condom protects people against STDs $(84.4 \%)$ and plays a vital role in STDs prevention (88.4\%). $82.3 \%$ and $78.9 \%$ of the respondents disagreed that condom was unnecessary during anal sex and if both partners were infected, respectively. Moreover, they disagreed that multiple sexual partners play no role in STDs' transmission (82\%) and the academic institution was unnecessary to discuss STDs prevention (83.9\%). Anyhow, $80.6 \%$ of them agreed that prostitution banning could control STDs cases. They also agreed that STDs' screening is useful (94.6\%) and important before getting married $(94.8 \%)$. The majority of the respondents
(74.9\%) believed that pornographic contents might lead to unsafe sexual practice. Besides, $74.6 \%$ of them opposed that STDs were curable; meanwhile, $79.8 \%$ of them felt STDs could cause death if left untreated. Most of the respondents were concerned (84.9\%) of contracting STDs; however, they admitted $(57.0 \%)$ on not given much thought about it. Also, $55.4 \%$ agreed that homosexual men were solely at fault for STDs spread. HIV (95.0\%) was the most concerning problem if they had unprotected sex, followed by other STDs (92.6\%) and unwanted pregnancy $(90.8 \%)$. The respondents agreed to seek treatment immediately if they $(96.0 \%)$ or their partners (95.8\%) were showing any symptoms. 
Table 2: Knowledge on STDs of University Students $(n=1,327)$

\begin{tabular}{|c|c|c|c|}
\hline \multicolumn{2}{|c|}{ Variables } & \multirow{2}{*}{$\begin{array}{c}\begin{array}{c}\text { Correct } n \\
(\%)\end{array} \\
1035(78.0)\end{array}$} & \multirow{2}{*}{$\begin{array}{c}\begin{array}{c}\text { Incorrect } n \\
(\%)\end{array} \\
292(22.0)\end{array}$} \\
\hline 1. & Have you ever heard of STDs? & & \\
\hline \multirow[t]{6}{*}{2.} & What are the causative organisms of STDs? & & \\
\hline & Bacteria & $966(72.8)$ & $361(27.2)$ \\
\hline & Virus & $917(69.1)$ & $410(30.9)$ \\
\hline & Fungus & $392(29.5)$ & $935(70.5)$ \\
\hline & Parasites & $183(13.8)$ & $1144(86.2)$ \\
\hline & Mosquitoes & $1321(99.5)$ & $6(0.5)$ \\
\hline \multirow[t]{11}{*}{3.} & Which of the following is an STD? & & \\
\hline & Gonorrhoea & $396(29.8)$ & $931(70.2)$ \\
\hline & Syphilis & $651(49.1)$ & $676(50.9)$ \\
\hline & Genital herpes & $762(57.4)$ & 565 (42.6) \\
\hline & Trichomoniasis & $95(7.2)$ & $1232(92.8)$ \\
\hline & Tuberculosis & $1291(97.3)$ & $36(2.7)$ \\
\hline & Asthma & $1281(96.5)$ & $46(3.5)$ \\
\hline & Hepatitis B & $1084(81.7)$ & $243(18.3)$ \\
\hline & Hepatitis C & $1184(89.2)$ & $143(10.8)$ \\
\hline & HIV/AIDS & $1089(82.1)$ & $238(17.9)$ \\
\hline & Chlamydia & $492(37.1)$ & $835(62.9)$ \\
\hline \multirow[t]{8}{*}{4.} & What are the routes of transmission of STDs? & & \\
\hline & Sexual intercourse & $1279(96.4)$ & $48(3.6)$ \\
\hline & Blood transfusion & $567(42.7)$ & $760(57.3)$ \\
\hline & Sharing injection needles & 707 (53.3) & $620(46.7)$ \\
\hline & Sharing food/drinks & $1225(92.3)$ & $102(7.7)$ \\
\hline & Sharing clothes & $1221(92.0)$ & $106(8.0)$ \\
\hline & Infected mother to child & $368(27.7)$ & $959(72.3)$ \\
\hline & Kissing & $421(31.7)$ & $906(68.3)$ \\
\hline \multirow[t]{9}{*}{5.} & What are the signs and symptoms of STDs? & & \\
\hline & Ulcers in genital organ & $840(63.3)$ & $487(36.7)$ \\
\hline & Pain while passing urine & 712 (53.7) & $615(46.3)$ \\
\hline & Swollen glands, fever and body ache & $347(26.1)$ & $980(73.9)$ \\
\hline & Discharge from penis & $735(55.4)$ & $592(44.6)$ \\
\hline & Discharge from vagina & $767(57.8)$ & $560(42.2)$ \\
\hline & Itching around the vagina & $704(53.1)$ & $623(46.9)$ \\
\hline & Sore throat & $80(6.0)$ & $1247(94.0)$ \\
\hline & Painless sores on the mouth and genital area & $442(33.3)$ & $885(66.7)$ \\
\hline 6. & Use of contraceptive pills can reduce STDs & $884(66.6)$ & $443(33.4)$ \\
\hline 7. & Use of condoms can decrease the risk of being infected with STDs & $1055(79.5)$ & $272(20.5)$ \\
\hline 8. & $\begin{array}{l}\text { Monogamy (having a sexual relationship with only one partner) can } \\
\text { reduce the chance of getting the STDs infection }\end{array}$ & $1135(85.5)$ & $192(14.5)$ \\
\hline 9. & Alcohol intake can increase an individual's susceptibility to STDs & $530(39.9)$ & $797(60.1)$ \\
\hline 10 & $\begin{array}{l}\text { Intake of some drugs can increase an individual's susceptibility to } \\
\text { STDs }\end{array}$ & $812(61.2)$ & $515(38.8)$ \\
\hline 11 & $\begin{array}{l}\text { Having multiple sexual partners can increase the chance of being } \\
\text { infected }\end{array}$ & $1250(94.2)$ & $77(5.8)$ \\
\hline 12 & Sexual abstinence is the most effective means of avoiding STDs & 1055 (79.5) & $272(20.5)$ \\
\hline 13 & Can people with STDs have no symptoms? & $696(52.4)$ & $631(47.6)$ \\
\hline \multirow[t]{6}{*}{14.} & What are the complications of STDs? & & \\
\hline & Infertility & $675(50.9)$ & $652(49.1)$ \\
\hline & Cervical cancer & 885 (66.7) & $442(33.3)$ \\
\hline & Body weakness & $800(60.3)$ & 527 (39.7) \\
\hline & Ectopic pregnancy & $351(26.5)$ & $976(73.5)$ \\
\hline & Stillbirth & $137(10.3)$ & $1190(89.7)$ \\
\hline
\end{tabular}


Related to the risk behaviours of the students, the finding shows $265(20 \%)$ of the respondents were sexually active. The majority of them stated that they did not inject $(98.9 \%)$ or took any drugs $(98.1 \%)$ or consumed any alcoholic drink (95.8\%) before having sex. Moreover, $94.3 \%$ of them declared that they did not have sex with commercial sex workers. About $45.4 \%$ of the respondents did read or watch pornographic materials, and $98.3 \%$ of them denied sharing injection needles with others. Table 3 represents the preventive practices of STDs among the respondents. $1062(80.0 \%)$ of them did abstain from having sex. Interestingly, only $9.9 \%$ of those who received a blood transfusion before was sure the blood was screened. Among the sexuallyactive students in the past 12 months, $53.8 \%$ of them had sex with only one partner, and $72.2 \%$ of them used condom. Even so, only $4.4 \%$ of them and their partners $(8.0 \%)$ got tested for STDs once a year.
Most of the respondents $(75.1 \%)$ were found to have good knowledge of STDs, and $53.8 \%$ of them have acceptable preventive practices (Table 4 ). There were significant associations between knowledge level on STDs with four demographic characteristics of respondents; study setting marital status, current semester, and academic cluster, where $\mathrm{p}$-values were $0.02,0.00,0.00$ and 0.00 . In addition, significant associations were found between preventive practices on STDs with three demographic characteristic of the respondents; marital status ( $p$-value: 0.00 ), residency of respondents ( $p$-value: 0.04) and academic cluster ( $p$-value: 0.01). Nevertheless, there was no association found between the knowledge level of the respondents with their preventive practices on STDs ( $p$-value: 0.81 ).

Table 3: Preventive Practices on STDs among University Students $(n=1,327)$

\begin{tabular}{|c|c|c|c|}
\hline \multicolumn{2}{|c|}{ Variables } & \multirow{2}{*}{$\begin{array}{r}\text { Yes } \mathbf{n}(\%) \\
1,062(80.0)\end{array}$} & \multirow{2}{*}{$\frac{\text { No } n(\%)}{265(20.0)}$} \\
\hline 1 & Do you abstain from having sex? & & \\
\hline 2 & $\begin{array}{l}\text { Have you ever received a blood transfusion? If Yes, are you } \\
\text { confirmed the blood is already being screened? If No, please } \\
\text { proceed to the next question. }\end{array}$ & & \\
\hline & & $131(9.9)$ & $1,196(90.1)$ \\
\hline \multirow[t]{2}{*}{3} & $\begin{array}{l}\text { For the past } 12 \text { months, did you have any sexual intercourse? } \\
\text { If Yes, do you have sex with only one partner? If No, please } \\
\text { proceed to question } 5 .\end{array}$ & & \\
\hline & & $129(46.2)$ & $150(53.8)$ \\
\hline 4 & Did you use a condom the last time you had sex? & & \\
\hline 5 & Do you get tested for STDs once a year? & $\begin{array}{r}192(72.2) \\
59(4.4)\end{array}$ & $\begin{array}{r}74(27.8) \\
1,268(95.6)\end{array}$ \\
\hline \multirow[t]{2}{*}{6} & $\begin{array}{l}\text { Does your partner get tested for STDs once a year? (Please } \\
\text { skip this question if you are single.) }\end{array}$ & & \\
\hline & & $31(8.0)$ & $356(92.0)$ \\
\hline
\end{tabular}

\section{DISCUSSION}

\section{Knowledge of sexually transmitted diseases}

This study showed that a good proportion of university students had a good understanding of STDs and have heard about STDs. As expected, HIV/AIDS was found to be the most commonly known STDs among the students. HIV/AIDS seems to be always given prime attention and discussed by the media most frequently compared to other STDs during health campaigns, hence explain why the other STDs were not recognized.

This study showed that the students had several misconceptions on STDs. Many did not know that STDs can be transmitted by infected mother to child $(72.3 \%)$ and kissing (68.3\%). Likewise, in Nigeria, $43.0 \%$ of the respondents believed that transmission is impossible through kissing ${ }^{11}$. It was disturbing that only $47.6 \%$ knew that STD might happen without showing signs. Similar findings were reported in the United States and
Ethiopia, as less than half of students there correctly indicated that STIs could be asymptomatic ${ }^{12-13}$.

Attitudes, risky behaviours and preventive practices on sexually transmitted diseases This study clearly showed that the students' good knowledge reflects on impressive attitudes and acceptable preventive practices. The majority of the students $(82.3 \%)$ thought protection is necessary during sexual intercourse, and $72.2 \%$ of them opted in using a condom in their sexual activity. A study found that students preferred to purchase condoms through vending machines ${ }^{14}$, as they feared of being publicly exposed and humiliated. The three most common obstacles to the use of condoms were the shame of being seen buying them, poor judgment due to alcohol consumption, and decreased in enjoyment ${ }^{15}$. 
Table 4: Associations of Knowledge and Preventive Practices on STDs with Demographic Characteristics

\begin{tabular}{|c|c|c|c|c|c|c|c|}
\hline Variables & & \multicolumn{2}{|c|}{ Knowledge Level } & $\begin{array}{c}\text { Statistical } \\
\text { Test, } x^{2} \\
(p \text {-value }) \\
\end{array}$ & \multicolumn{2}{|c|}{ Preventive Practice } & \multirow{2}{*}{$\begin{array}{c}(p- \\
\text { value })\end{array}$} \\
\hline Total $(n=1327)$ & & $\begin{array}{c}\begin{array}{c}\text { Poor } \\
\text { n (\%) }\end{array} \\
330(24.9)\end{array}$ & $997(75.1)$ & & $\begin{array}{c}\begin{array}{c}\text { Unacceptable } \\
\text { n (\%) }\end{array} \\
613(46.2 \%)\end{array}$ & $\begin{array}{c}\begin{array}{c}\text { Acceptable } \\
\text { n (\%) }\end{array} \\
714(53.8)\end{array}$ & \\
\hline \multicolumn{8}{|l|}{ Age } \\
\hline & $19-23$ & $284(86.1)$ & $826(82.8)$ & \multirow[t]{2}{*}{$\begin{array}{r}1.87 \\
(0.17)\end{array}$} & $272(81.2)$ & $838(84.5)$ & \multirow[t]{2}{*}{$\begin{array}{r}1.97 \\
(0.16)\end{array}$} \\
\hline & Older than 23 Years Old & $46(13.9)$ & $171(17.2)$ & & $63(18.8)$ & $154(15.5)$ & \\
\hline \multicolumn{8}{|l|}{ Study Setting } \\
\hline & Puncak Alam Campus & $158(47.9)$ & $395(39.6)$ & \multirow{3}{*}{$\begin{array}{r}7.43 \\
(0.02)\end{array}$} & $146(43.6)$ & $407(41.0)$ & \multirow{3}{*}{$\begin{array}{r}1.55 \\
(0.46)\end{array}$} \\
\hline & Shah Alam Campus & $143(43.3)$ & $486(48.7)$ & & $158(47.2)$ & $471(47.5)$ & \\
\hline & Puncak Perdana Campus & $29(8.8)$ & $116(11.6)$ & & $31(9.3)$ & $114(11.5)$ & \\
\hline \multicolumn{8}{|l|}{ Gender } \\
\hline & Male & $111(33.6)$ & 318 (31.9) & \multirow{2}{*}{$\begin{array}{r}0.34 \\
(0.56)\end{array}$} & $118(35.2)$ & $311(31.4)$ & \multirow{2}{*}{$\begin{array}{r}1.72 \\
(0.19)\end{array}$} \\
\hline & Female & $219(66.4)$ & $679(68.1)$ & & $217(64.8)$ & $681(68.6)$ & \\
\hline \multicolumn{8}{|l|}{ Ethnic } \\
\hline & Malay & $321(97.3)$ & $974(97.7)$ & \multirow{2}{*}{$\begin{array}{r}0.19 \\
(0.67)\end{array}$} & $328(97.9)$ & 967 (97.5) & \multirow{2}{*}{$\begin{array}{r}0.20 \\
(0.66)\end{array}$} \\
\hline & Others & $9(2.7)$ & $23(2.3)$ & & $7(2.1)$ & $25(2.5)$ & \\
\hline \multicolumn{8}{|l|}{ Marital Status } \\
\hline Single & $281(85.2)$ & $663(66.5)$ & \multirow[t]{4}{*}{$\begin{array}{l}42.99 \\
(0.00)\end{array}$} & $120(35.8)$ & $824(83.1)$ & \multirow[t]{4}{*}{$\begin{array}{r}276.29 \\
(0.00)\end{array}$} & \\
\hline In a relationship & $46(13.9)$ & $320(32.1)$ & & $202(60.3)$ & $164(16.5)$ & & \\
\hline Engaged & $1(0.3)$ & $9(0.9)$ & & $8(2.4)$ & $2(0.2)$ & & \\
\hline Married & $2(0.6)$ & $5(0.5)$ & & $5(1.5)$ & $2(0.2)$ & & \\
\hline \multicolumn{8}{|l|}{ Educational Level } \\
\hline Diploma & $11(3.3)$ & $48(4.8)$ & \multirow[t]{2}{*}{$\begin{array}{r}1.28 \\
(0.26)\end{array}$} & $14(4.2)$ & $45(4.5)$ & $0.08(0.78)$ & \\
\hline Bachelor & $319(96.7)$ & $949(95.2)$ & & $321(95.8)$ & $947(95.5)$ & & \\
\hline Current Semester & & & & & & & \\
\hline 1 & $0(0.0)$ & $11(1.1)$ & $\begin{array}{l}35.63 \\
(0.00)\end{array}$ & $2(0.6)$ & $9(0.9)$ & $8.84(0.26)$ & \\
\hline 2 & $29(8.8)$ & $56(5.6)$ & & $23(6.9)$ & $62(6.3)$ & & \\
\hline 3 & $30(9.1)$ & $88(8.8)$ & & $40(11.9)$ & 78 (7.9) & & \\
\hline 4 & $77(23.3)$ & $197(19.8)$ & & $58(17.3)$ & $216(21.8)$ & & \\
\hline 5 & $71(21.5)$ & $124(12.4)$ & & $52(15.5)$ & $143(14.4)$ & & \\
\hline 6 & $67(20.3)$ & $257(25.8)$ & & $82(24.5)$ & $242(24.4)$ & & \\
\hline $\begin{array}{l}7 \\
8\end{array}$ & $\begin{array}{l}45(13.6) \\
11(3.3)\end{array}$ & $\begin{array}{r}202(20.3) \\
62(6.2)\end{array}$ & & $\begin{array}{r}57(17.0) \\
21(6.3)\end{array}$ & $\begin{array}{r}190(19.2) \\
52(5.2)\end{array}$ & & \\
\hline Residency & & & & & & & \\
\hline Resident & $155(47.0)$ & $443(44.4)$ & $\begin{array}{r}0.64 \\
(0.42)\end{array}$ & 167 (49.9) & 431 (43.4) & $4.15(0.04)$ & \\
\hline Non-resident & $175(53.0)$ & $554(55.6)$ & & $168(50.1)$ & $561(56.6)$ & & \\
\hline Academic Cluster & & & & & & & \\
\hline Science \& Technology & $109(33.0)$ & $459(46.0)$ & $\begin{array}{l}70.46 \\
(0.00)\end{array}$ & $168(50.1)$ & $400(40.3)$ & $10.61(0.01)$ & \\
\hline Social Science \& Humanities & $122(37.0)$ & $430(43.1)$ & & $126(37.6)$ & $426(42.9)$ & & \\
\hline Business \& Management & $99(30.0)$ & $108(10.8)$ & & $41(12.2)$ & $166(16.7)$ & & \\
\hline
\end{tabular}

Although, majority of the students in this study correctly identified that monogamy $(82.0 \%)$ helps to reduce the risk of STDs infection, surprisingly, half of the students who were sexually active for the past 12 months, had sex with more than one partner. Likewise, a study at Klang Valley revealed that despite having immense knowledge of preventive practices, more than half of the participants admitted having three or more sexual partner ${ }^{16}$. Thereby, having complete understanding on its own does not always guarantee the behaviour and practice of a person.

Despite the students practising safe sexual behaviours, more than half $(54.6 \%)$ of them did read or watch pornographic materials. Adult contents had been closely correlated with 
sexual behaviour in young adults ${ }^{17-18}$, and a study from the United States revealed that youths who exposed to those contents tend to have sex ${ }^{19}$. The study also showed that early exposure to pornographic media could lead to permissive sexual norms and behaviours, especially for males.

\begin{abstract}
Associations between knowledge and preventive practices of sexually transmitted diseases with socio-demographic factors

In this study, the Shah Alam campus which located in an urban area had the highest number of students with good knowledge compared to other campuses in the suburban areas. The exposure from the surrounding and lifestyle somehow affecting the students' knowledge regarding STDs. Besides, students from higher semester reported having better STDs' knowledge than their juniors. As students became seniors, their curiosity and development prompted them to explore more information on sexual issues. These outcomes were coherent with a study on Malaysian university students, as the finding suggests that first-year students did not know much about sexual health ${ }^{20}$.
\end{abstract}

It was interesting to note that marital status was found to correlate not only to the students' level of knowledge but also with their preventive practices. Single students were reported to have a higher level of knowledge on STDs and acceptable preventive practices than those with a partner. Single individuals were not committed to a monogamous relationship; hence they were more concerned about getting infected and took precautions. In contrary, a local study showed the married and older students had higher mean knowledge score compared to single students ${ }^{8}$.

Furthermore, this study discovered that university students who lived outside the campus practised acceptable preventive practices compared to campus dwellers. These findings were consistent with a study that reported that the non-resident students were documented to have better preventive practices on STDs than the boarding students by utilizing a condom $^{21}$.

The results obtained in this study suggested that students in the Science and Technology academic cluster had higher STDs knowledge than students from other academic clusters. It may be because university courses in this academic cluster, include topics related to sexual and reproductive health. However, despite having a good knowledge of STDs, students in this academic cluster perceived unacceptable preventive practices. A study among Chinese university students discovered that students with prior knowledge of STDs exhibited misconceptions about STDs preventions due to their false confidence in self-protection, which leads to higher rates of sexual practice ${ }^{22}$. A higher knowledge level alone could not ensure responsible behaviour ${ }^{23}$. Hence, the students need to be educated more on preventive actions despite only focusing on the understanding of STDs.

\section{Limitation and Recommendation}

Despite that, the desired number of participants were successfully collected. The results of the study may had the limited applicability for university students, as this study only covered three campuses in only one state. Even then, considering the relatively large sample size and the evenly distributed number of students from each faculty, the results should be able to define other students at the university. One recommendation was to do the same study throughout all different campuses in different regions of the country in order to perform a comparative analysis and the involving foundation and postgraduate students to gain insight into university students' knowledge, attitude and preventive practices towards STDs and risky sexual behaviour as a whole. This would enable future research to reach conclusions regarding the general university students and improve current intervention strategies. Since the study was carried out for an educational purpose, it might serve as a tool for institutions to study the need for education to promote safe sexual health among students. Besides, to maintain continuous and effective sex education, it is vital to have a set of sex education programs for university students that are compulsory for them to attend.

\section{CONCLUSION}

This study sought to explore the knowledge, attitudes, risky behaviours and preventive practices of university students towards STDs. Despite the presence of proper knowledge and favourable attitudes, almost half of participating university students had unacceptable preventive practices on STDs, raising concerns about a likely future rise in STD incidence. The study highlighted some misconceptions about STDs which need to be addressed. Therefore, interventions to implement strengthened health education on STD-related issues were required to bring change in practices, along with knowledge and attitudes. People should also be encouraged to learn about these issues. Society's narrowmindedness was believed to be a barrier in searching for more information about sexual health. Education not only from the learning institutions but also from family and society was highly valued in this matter.

\section{Acknowledgement}

We are grateful to UiTM for supporting this 
study. We thank the study participants for their willingness to be part of this study.

\section{REFERENCES}

1. World Health Organization. (2020). Massive proportion of world's population are living with herpes infection. Department News. Retrieved from https: //www. who.int/newsroom/detail/01-05-2020-massiveproportion-of-world-s-population-areliving-with-herpes-infection

2. Centers for Disease Control and Prevention. STDs in Adolescents and Young Adults - 2016 STD Surveillance Report. Centers Dis Control Prev. 2017

3. Audinarayana, N. (2010). Sexual Behaviour and Its Determinants among Young Never-married Male Factory Workers in a South Indian Knit City. 18(2), 155-174.

4. Da Ros CT, Da Silva Schmitt C. Global epidemiology of sexually transmitted diseases. Asian J Androl. 2008;10(1):110-4.

5. Ministry of Health. (2019). Country Progress Report on HIV / AIDS Response.

6. Awang H, Wong LIP, Jani R, Low Wahyun. Knowledge Of Sexually Transmitted Diseases And Sexual Behaviours Among Malaysian Male Youths. 2014;214-24.

7. Doster A, Doster AM. The Knowledge of Sexually Transmitted Diseases Among College Students. 2018.

8. Soleymani S, Abdul Rahman H, Lekhraj R, Mohd Zulkefli NA, Matinnia N. A crosssectional study to explore postgraduate students' understanding of and beliefs about sexual and reproductive health in a public university, Malaysia. Reprod Health. 2015;12(1).

9. Folasayo AT, Oluwasegun AJ, Samsudin S, Saudi SNS, Osman M, Hamat RA. Assessing the knowledge level, attitudes, risky behaviors and preventive practices on sexually transmitted diseases among university students as future healthcare providers in the central zone of Malaysia: A crosssectional study. Int J Environ Res Public Health. 2017;14(2):1-14.

10. Svensson, Linn SW. Knowledge of and attitudes to sexually transmitted diseases among Thai university students. Caring Sci. 2013;18-21.
11. Edith M. Awareness of Sexually Transmitted Infections (STIs) Including HIV/AIDS among Undergraduate Students of University of Abuja, Nigeria. Br J Appl Sci Technol. 2014;4(4):705-17.

12. Nsuami JM, Sanders LS, Taylor SN. American Journal of Health Education. (October 2014):37-41.

13. Mulu W, Abera B, Yimer M. Knowledge, attitude and practices on HIV / AIDS among students of Bahir Dar University. Sci J Public Heal. 2014;2(2):78-86.

14. Bell J. Why embarrassment inhibits the acquisition and use of condoms: A qualitative approach to understanding risky sexual behaviour. J Adolesc [Internet]. 2009;32(2):379-91. Available from:

http://dx.doi.org/10.1016/j.adolescenc e.2008.01.002

15. King KA, Vidourek RA. Condoms, Sex , and Sexually Transmitted Diseases: Exploring Sexual Health Issues Among Asian-Indian College Students. 2014.

16. Zin NM, Ishak I, Manoharan K. Knowledge, attitude and practice towards sexually transmitted diseases amongst the inmates of women shelters homes at Klang Valley. BMC Public Health. 2019;19(Suppl 4):1-7.

17. Awaluddin SM. Prevalence of sexual activity in older Malaysian adolescents and associated factors. 2015; (January).

18. Manaf MRA, Tahir MM, Sidi $H$, Midin $M$, Jaafar NRN, Das S, et al. Pre-marital sex and its predicting factors among Malaysian youths. Compr Psychiatry [Internet]. 2014;55(SUPPL. 1):S82-8. Available from: http://dx.doi.org/10.1016/j.comppsych .2013.03.008

19. Brown JD, L'Engle KL. X-rated: Sexual attitudes and behaviors associated with U.S. early adolescents' exposure to sexually explicit media. Communic Res. 2009;36(1):129-51.

20. Jahanfar S, Lye MS, Rampal L. A randomised controlled trial of peeradult-led intervention on improvement of knowledge, attitudes and behaviour of university students regarding HIV/AIDS in Malaysia. Singapore Med J. 2009;50(2):173-80. 
21. Matias N, Priscilla $\mathrm{R}$ e $\mathrm{SN}$, Carlos LT, Daniela CC, Erika AS. Health-risk behavior differences between boarding and non-resident students: Brazilian adolescent National School Health Survey. Arch Public Heal. 2020;78(1):19.

22. Zhang D, Pan H, Cui B, Law F, Farrar J, Ba-Thein W. Sexual behaviors and awareness of sexually transmitted infections among Chinese university students. J Infect Dev Ctries. 2013;7(12):966-74.
23. Anwar M, Syed Azhar SS, Keivan A, Tahir MK. Awareness of school students on sexually transmitted infections (STIs) and their sexual behavior: a crosssectional study conducted in Pulau Pinang, Malaysia. BMC Public Health [Internet]. 2010;10:47. Available from: http: / / ovidsp.ovid.com/ovidweb.cgi?T= JS\&PAGE=reference\&D=emed9\&NEWS $=\mathrm{N}$ $\& A N=20113511$ 